\title{
The Development of Stem Cell-derived Exosomes as a Cell-free Regenerative Medicine
}

\author{
Review Article
}

\author{
Indira Vishnubhatla ${ }^{1}$, Randolph Corteling ${ }^{1}$, Lara Stevanato ${ }^{1}$, Caroline Hicks $^{1}$ and John Sinden ${ }^{1, *}$ \\ 1 ReNeuron Ltd, Surrey Research Park, Guildford, UK \\ * Corresponding author E-mail: John-Sinden@reneuron.com
}

Received 11 Mar 2014; Accepted 5 Apr 2014

DOI: $10.5772 / 58597$

(c) 2014 The Author(s). Licensee InTech. This is an open access article distributed under the terms of the Creative Commons Attribution License (http://creativecommons.org/licenses/by/3.0), which permits unrestricted use, distribution, and reproduction in any medium, provided the original work is properly cited.

Abstract A successful strategy in regenerative medicine over the last decade has been the translation of stem cell therapy to repair diseased or damaged tissue in a wide range of indications, despite limited evidence attributing any therapeutic benefit to cell survival or differentiation. Recent findings, however, have demonstrated that the conditioned media from stem cell cultures can produce similar efficacious effects compared to those observed for cells. This has led to the stem cell paracrine hypothesis, proposing that secreted factors released from the stem cells contribute significantly to their beneficial effects. It has been well documented that stem cells have the ability to release a range of growth factors, cytokines and chemokines relevant to their function; however, these factors are released at levels too low to account for the reported therapeutic effects. Further purification of the conditioned media has since identified that not only are small molecules released by the stem cells, but so too are a large quantity of membrane-bound vesicles, including exosomes, in a functionally relevant manner. In this review, we present our current understanding and explore the evidence supporting the development of stem cell-derived exosomes as a cell-free regenerative medicine.

Keywords Exosomes, Characterization, Isolation, Therapeutic Potential

\section{Introduction}

One major approach to regenerative medicine has been to replace lost tissue with new cellular material or facilitate the regeneration of damaged or diseased tissues by means of stem cell transplantation. Over the last two decades, therapeutic options have progressed from the grafting of whole tissue (such as bone marrow) to the injection of autologous or allogeneic stem cell products derived from adipose, blood, bone and brain tissue. More recently, pluripotent cells derived from embryonic stem (ES) cells or induced pluripotent stem (iPS) cells, using cellular reprogramming technologies, have been the source of new potential cell therapies. The translation of stem cell therapies from bench to clinic has been 
remarkable, with thousands of trials currently registered in the National Institutes of Health clinical trials database (www.clinicaltrials.gov). The investigations span a broad range of indications, from microbial diseases, cancers and neoplasms, congenital, heart and blood disorders, nervous system diseases, immune disease (graft versus host, multiple sclerosis, arthritis and colitis), wounds and injuries. Results from the early phase trials have demonstrated cell therapy as safe, feasible and - in a number of indications - potentially efficacious, for example, in cardiology [1], ischaemic stroke [2], peripheral ischaemia [3] and cancer [4]. However, for many of these therapies, evidence of a therapeutic benefit cannot be attributed to stem cell survival and/or differentiation [5-7]. The beneficial effects of cell implants without long-term cell survival together with observed trophic effects of the cell-conditioned culture medium suggest that secreted paracrine factors may be involved $[8,9]$. Small molecules (i.e., growth factors, chemokines and cytokines) are secreted at too low levels to account for the therapeutic efficacy reported [10]. However, the paracrine hypothesis has been strengthened by the recent discovery that stem cells release not only soluble factors but also extracellular vesicles which elicit similar biological activity to the stem cells themselves [11-14].

The most prominent of the extracellular vesicles are exosomes. Exosomes have been shown to play a key role in cell-to-cell communication [15-20] and modulating cellular immunity [21-24]. Recent data suggest that exosomes may physically link beneficial outputs from stem cells to neighbouring diseased or injured cells through the delivery and transfer of protein, bio-active lipid and nucleic acid cargo, inducing phenotypic and functional changes in the recipient cells that promote the activation of regenerative programs [25-28]. The paracrine hypothesis has inspired an alternative approach in regenerative medicine: namely, translating the potential clinical applications based on exosomes secreted by the stem cells rather than the stem cells themselves, an approach underpinned by the discovery of the control system for the transport and delivery of cellular cargo for which E. Rothman, R.W. Schekman and T. C. Südhof received the 2013 Nobel Prize for Medicine (www.nobelprize.org).

\section{Formation, release and function of exosomes}

Stem cell-derived exosomes have now been identified and isolated from cell culture supernatants of several cell types with known therapeutic potential, including mesenchymal stromal (MSC) [29-31], (bone marrow stem cells) mononuclear (MNC) [32], immune cells (dendritic and CD34+) [33, 34] and human neural stem cells (hNSCs) $[35,36]$. Exosomes $(30-100 \mathrm{~nm})$ can be

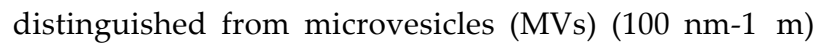

and apoptotic bodies $(1-5 \mu \mathrm{m})$ by size and morphology [37-39]. Exosomes are lipid bilayer-bound vesicles, released from cells after stimulation [40], and they express specific biomarkers independently of the cell source that will be detailed below. Unlike MVs, which are derived from plasma membrane shedding, exosomes are secreted by multivesicular bodies (MVBs) [38, 41-44]. Exosomes produced from a single cell can comprise a heterogeneous population of vesicles that may feature different markers, compositions and, potentially, different functions [40]. The heterogeneity of their composition, along with their stable physicochemical features, has led to the idea of using exosomes as natural nano-devices for the development of new therapeutic applications [45-48].

Once released into the extracellular environment, exosomes may interact with recipient cells via adhesion to the cell surface mediated by lipid-ligand receptor interactions, internalization via endocytic uptake, or by direct fusion of the vesicles and cell membrane, which leads to the release of exosome content into the target cell $[15,49]$. The net result of exosome-cell interactions is the modulation of the physiology of the target cell, induced through any of several different mechanisms, ultimately influencing the biology of tissue/the organism as a whole. The interactions involve many physiological processes, such as antigen presentation [50,51], the transfer of RNA [28] and tissue repair [30]. Exosomes have been found to carry antigenic materials and express functional major histocompatibility (MHC) complexes, giving them the potential to mediate antigen-specific immune responses [52]. For example, tumour-derived exosomes captured by dendritic cells can induce the activation of antigenspecific T-cells not previously exposed to the tumour antigen [21, 23], and the function of follicular dendritic cells has been attributed to membrane-bound exosomes containing MHC class II [53].

Exosomes can also influence the biology of recipient cells via the delivery of bioactive content into target cells through the internalization of vesicles. The bilayer membrane encapsulation of exosomes provides a protected and controlled internal microenvironment, allowing cargo to travel long distances within tissues without degradation [27, 28, 54-56]. Most recent developments implicate a major role for the horizontal transfer of proteins and genetic materials (such as mRNA, microRNA (miRNA), pre-miRNAs, and other non-coding RNAs) in the reprogramming of recipient cells. ES cellderived exosomes have been demonstrated to shuttle/transfer mRNA and proteins to hematopoietic progenitors [26]. Other studies have shown that adult stem cell-derived exosomes also shuttle selected patterns of mRNA, miRNA and pre-miRNA associated with several cellular functions involved in the control of 
transcription, proliferation and cell immune regulation [57-60].

\section{Exosomal features}

\subsection{Membrane composition}

Besides their characteristic morphology, exosomes are unique in their bilayer membrane protein and lipid composition compared to other extracellular vesicles. Exosomal membrane components have been proposed as playing pivotal roles, such as signalling molecules in the uptake/fusion of exosomes with target cells and propagation of signalling in immune responses. For example, Rab GTPase membrane proteins have been implicated in membrane trafficking and secretion [61,62].

\subsection{Lipid rafts}

Lipid rafts are structurally and functionally unique microdomains in the cell membrane surface which function as sites for key membrane activities, such as endocytosis, cell adhesion and membrane trafficking [63]. Lipid rafts, tightly packed areas of sphingolipids and cholesterol compared to the surrounding areas, have been reported in both cellular and exosomal (including stem cell-derived) membranes [64]. As a consequence of the lipids' composition and limited size, exosomes have a more rigid membrane than their parent cell [65]. High levels of ceramide (associated with biogenesis and release) have also been reported in exosomes [66]. Lipid rafts reflect the endosomal origin of exosomes and represent a distinctive feature, which may be useful for their differentiation and isolation from other secreted microparticles [65].

\subsection{Proteins}

Exosome membranes comprise both ubiquitous and cell type-specific proteins that cover numerous biological functions. A complete database of exosomal proteins can be found at ExoCarta (www.exocarta.org) [67]. Due to their endosomal origin, all exosomes contain membrane transport and fusion proteins (annexins, GTPases, flotillin), tetraspanins (CD9, CD63, CD81, CD82), heat shock proteins (Hsp70, Hsp90), proteins involved in multivesicle body biogenesis (Alix and TSG101), lipidrelated proteins and phospholipases [29,68]. These proteins have been associated with lipid rafts. Due to their size, lipid rafts can contain only a few proteins at one domain. To engage in a membrane function, lipid rafts cluster together and sequester specific sets of signalling and other proteins which serve as platforms to execute functions such as membrane trafficking and signalling [61].
Proteins presented on the outer exoplasmic membrane layer are routinely used as identifying markers; however, there is wide variation in terms of protein profiles across exosomes from different cell sources. The most widelyused markers are tetraspanins, Alix, flotillin, TSG101 and Rab5b, which are detected using antibody-based techniques (such as Western blot or ELISA) for the rapid confirmation of the presence of exosomes.

\subsection{Cargo contents}

Exosomal cargo can contain a variety of cytoplasmic nucleic acids, lipids and proteins, reflecting both the condition and origin of the parent or producer cell. As a result, exosomes exhibit some commonly shared contents and express distinctive molecules identifying their originating producer cell, but they also possess unique mixtures of proteins and RNA. The complexity of cargo contents has been postulated as a significant factor of exosomal efficacy in treating complex tissue injuries such as those that affect multiple tissues and targets [69]. Individual components in the cargo may not be equally or sufficiently efficacious, and the therapeutic efficacy of exosomes in relation to a specific injury may result from the synergy of a select permutation of individual exosome components. One aim of translational research is to assess the biochemical activities of these contents and identify the optimal permutations of these activities for therapeutic targets.

There is a growing need for quick and easy methods for the analysis of exosomal cargo. The thorough molecular characterization of exosomes is hindered by the complexity of their composition, their high heterogeneity and their low abundance. To date, only a few studies have been conducted that have provided a systematic characterization of the protein and the genetic composition of stem cell-derived exosomes $[29,35,57,58$, 69-71] (Table 1).

A number of proteins have been identified in the functional cargo of stem cell-derived exosomes which affect a variety of cellular functions [14, 18, 26, 49, 72, 73]. Recent developments in protein separation techniques, spectrometry, immunological methods and bioinformatics have enabled the systematic characterization of MSCderived exosomes [29, 68, 69] (Table 1). These analyses have identified over 700 proteins that reflect: (1) the evolutionary conserved set of exosomal proteins (CD81, CD63, CD9 [tetraspanins], Alix, Tsg101) and those tissue or cell type-specific proteins; (2) integration of parental cellular processes and genes of self-renewal and differentiation; and (3) a list of proteins that can be associated with therapeutic potential [29]. 


\begin{tabular}{|c|c|c|}
\hline $\begin{array}{l}\text { Functional Group / } \\
\text { Component }\end{array}$ & Constituent Type (description) & Exosome Source / Reference \\
\hline Surface receptors & $\begin{array}{l}\text { Platelet-derived growth factor receptor beta (PDGF-R } \beta \text { ) } \\
\text { Epidermal growth factor receptor (EGFR) } \\
\text { Plasminogen activator, urokinase receptor (PLAUR) }\end{array}$ & hBM-MSC [29] \\
\hline \multirow[t]{2}{*}{$\begin{array}{l}\text { Signalling } \\
\text { molecules }\end{array}$} & $\begin{array}{l}\text { R-Ras / N-RAS } \\
\text { Mitogen-activated protein kinase 1(MAPK1) } \\
\text { Guanine nucleotide binding protein } 13 \text { (GNA13) } \\
\text { Guanine nucleotide binding protein (G protein), gamma } 12 \text { (GNG12) } \\
\text { Cell division cycle } 42 \text { (CDC42) } \\
\text { Guanine nucleotide exchange factor (VAV2) }\end{array}$ & hBM-MSC [29] \\
\hline & $\begin{array}{l}\text { Ras-related Rab proteins } \\
\text { Laminin-R } \\
14-3-3 \text { proteins }\end{array}$ & hBM-MSC [29] \\
\hline \multirow[t]{2}{*}{ Cell adhesion } & $\begin{array}{l}\text { Fibronectin 1 (FN1) } \\
\text { Ras GTPase-activating-like protein } 1 \text { (IQGAP1) } \\
\text { CD47 } \\
\text { EZR } \\
\text { Integrins } \\
\text { Lectin, galactose binding, soluble } 1 \text { (LGALS1) } \\
\text { Lectin, galactoside-binding, soluble, } 3 \text { (LGALS3) }\end{array}$ & hBM-MSC [29] \\
\hline & CD34 & hCD34+ and MNC[34] \\
\hline \multirow[t]{6}{*}{$\begin{array}{l}\text { MSC-associated } \\
\text { antigens }\end{array}$} & CD63 & $\begin{array}{l}\text { hBM-MSC [29]; hCD34+ and } \\
\text { MNC [34] }\end{array}$ \\
\hline & CD109, CD151 & hBM-MSC [29] \\
\hline & CD248, and CD276 & hBM-MSC [29] \\
\hline & CD13, CD73, CD105 & hBM-MSC [29] \\
\hline & $\begin{array}{l}\text { CD29, CD44, CD73, CD90, and } \\
\text { CD105 positivity (MSC markers) }\end{array}$ & hBM-MSC[29] \\
\hline & CD9, CD81 & $\begin{array}{l}\text { hBM-MSC[29], hCD34+ and } \\
\text { MNC [34]; hESC-MSC [64] }\end{array}$ \\
\hline \multirow[t]{4}{*}{$\begin{array}{l}\text { Raft-associated } \\
\text { proteins }\end{array}$} & Transluminal protein (TSG101) & $\begin{array}{l}\text { hCD34+ and MNC [34]; } \\
\text { hESC-MSC [64] }\end{array}$ \\
\hline & Annexin V (bound to Phosphatidylserine) & hCD34+ and MNC [34] \\
\hline & Alix / actin interacting protein 1 (AIP1) & hESC-MSC $[30,64,104]$ \\
\hline & $\begin{array}{l}\text { Heat shock protein } 70 \mathrm{KDa} 1 \mathrm{~A} \text { variant } \\
\text { Transferrin receptor } \\
\text { HLA-DR4 } \\
\text { Ezrin }\end{array}$ & hNSC [35] \\
\hline \multirow[t]{2}{*}{$\begin{array}{l}\text { Raft-associated } \\
\text { lipids }\end{array}$} & $\begin{array}{l}\text { GM1 gangliosides } \\
\text { Sphingomyelin } \\
\text { Ceramide }\end{array}$ & hESC-MSC [64] \\
\hline & Phosphatidylserine & hCD34+ and MNC[36] \\
\hline \multirow[t]{2}{*}{ Novel protein cargo } & $\begin{array}{l}\text { Prostaglandin G/H synthase (cell proliferation) } \\
\text { Cathepsin F precursor (intracellular degradation and turnover of proteins) } \\
\text { Sarcoma antigen } 1 \text { (tumour marker) } \\
\text { Polymyositis/scleroderma (autoantigen to nuclear proteins) }\end{array}$ & hNSC [35] \\
\hline & $\begin{array}{l}\text { 20S Proteasome (degradation of misfolded proteins related to tissue damage } \\
\text { in MI) }\end{array}$ & hESC-MSC [69] \\
\hline \multirow{6}{*}{$\begin{array}{l}\text { Functional genetic } \\
\text { cargo }\end{array}$} & MiRNA126 and MiRNA 130a (angiogenesis) & hCD34+ and MNC [34] \\
\hline & MiRNA133b (stroke recovery) & Mouse MSC [104, 111] \\
\hline & MiRNA 96, miRNA124 and miRNA199a (differentiation) & hBM- MSC[115] \\
\hline & $\begin{array}{l}\text { MiRNA } 451 \text { (maintenance, differentiation) } \\
\text { MiRNA } 223 \text { (regulator of cell cycle) }\end{array}$ & hBM-MSC and HLSC [58] \\
\hline & $\begin{array}{l}\text { MiRNA } 335 \text { (markers of cell of origin for BM-derived MSCs) } \\
\text { MiRNA } 564 \text { (selective expression in MSC exosomes compared to MSCs) }\end{array}$ & hBM-MSC[58] \\
\hline & $\begin{array}{l}\text { MiRNA 142-3p, miRNA } 501 \text { (selective expression in HLSC exosomes } \\
\text { compared to HLSCs) }\end{array}$ & HLSC[58] \\
\hline
\end{tabular}

Abbreviations: BM, Bone marrow; hESC, human embryonic stem cells; hNSC, human neural stem cells; HLSC, human liver resident stem cells; hMSC, human mesenchymal stem cell; MI, Myocardial infarction; miRNA, micro-RNA; MNC, mononuclear cells

Table 1. Examples of functional components isolated from stem cell-derived exosomes 


\section{Proteomic characterization}

Techniques such as Shotgun proteomic analysis of the peptide mixtures from exosomal fractions have been used to identify proteins from hNSCs [35]. A total of 103 proteins were detected in a sample of hNSC-derived exosomes, including previously reported heat shock 70 $\mathrm{kDa}$, transferrin receptor, HLA DR4 and ezrin, and several as yet unreported such as anhydrolase-domaincontaining-8, G protein-coupled receptor associated sorting protein 1 , the $70 \mathrm{kDa}$ heat shock protein $1 \mathrm{~A}$ variant, and prostaglandin $\mathrm{G} / \mathrm{H}$ synthase. Rarer proteins such as cathepsin $\mathrm{F}$ precursor and sarcoma antigen 1 which were also detected were uniquely present in only one fraction (Table 1).

\section{Genetic information in stem cell-derived exosomes}

Mitochondrial DNA, mRNA and non-coding RNAs such as miRNA have been reported in stem cell-derived exosomes and may deliver horizontal gene transfer to target cells [11, 74, 75]. Exosomes derived from human stem cells have been shown in vivo to deliver human mRNA to mouse cells, resulting in protein translation [76, 77]. Exosomes derived from ES cells contain abundant miRNA and have been demonstrated to transfer a subset of miRNAs to mouse embryonic fibroblasts in vitro [60].

MiRNA is a class of small, non-coding RNA molecules consisting of 19 to 24 nucleotides that have a variety of cellular properties associated with both physiological and pathological processes. They are involved in homeostasis, the post-translational modification of gene expression, oncogenesis and tumour suppression, RNA and protein complex shuttling, and protection from RNase enzymatic degradation [20, 78-83]. Exosomes provide a protected and controlled internal microenvironment, allowing miRNA molecules to travel long distances within tissues without degradation [54]. Evidence suggests that miRNA packaging occurs non-randomly and that specific miRNA populations are preferentially sorted and shuttled into MVs [84], and secreted contents could vary in response to different stimuli [58]. Important questions, regarding how miRNAs are sorted into exosomes (shedding vesicles and high density lipoprotein (HDL) particles), whether there is regulated specificity in this process, how secreted vesicles are taken up by recipient cells and whether specific cells are targeted, need to be addressed.

The transfer of human mRNA via exosomes and its translation into protein have been observed both in vitro and in vivo in diverse experimental models [28]. RNA inactivation resulted in the significant loss of biological activities, suggesting that the transfer of nucleic acids has a relevant role [85]. However, exosomes also transfer regulators of transcription as they induce changes in the gene expression of the recipient cells, such as the upregulation of the BCL family genes and the downregulation of CASP1 (caspase 1), CASP8 (caspase 8) and LTA (lymphotoxin $\alpha$ ) genes involved in the "execution" phase of cell apoptosis [80].

Moreover, the miRNAs present in exosomes are candidates for the post-transcriptional regulation and induction of epigenetic changes in the recipient cells. miRNAs shuttled by EPC-derived MVs are the main effectors of the pro-angiogenic and renoprotective activities of MVs [79]. In fact, the non-specific as well as the specific depletion of miRNAs in MVs obtained from Dicer- or miRNA126- and miRNA-296-knockdown EPCs modify their biological effects $[79,86]$.

The number of secreted miRNAs identified in stem cellderived exosomes has been expanding (Table 1) and their role and biological/physiological significance is of considerable interest. Stem cell types and their derived exosomes have distinct miRNA profiles [34, 86, 87], and are listed in http://exocarta.org/mirna and http://www.mirbase.org.

\subsection{Producer cells}

To ensure the large scale supply required for clinical research and development, producer cell immortalization (either by natural selection or by genetic modification) and clonal isolation is a practical strategy to produce functionally bioactive exosomes for use as therapeutic agents or delivery vehicles [47, 88, 89]. Immortalization ensures production stability and reduces the equivalence testing of new production lots. Bioreactors and other specialized culture systems are also used for culture expansion and to increase the yields of exosomes and MVs $[88,90]$. In respect of genetically modified producer cells, the immortalizing oncogene (e.g., c-myc) and its protein product are not trafficked into the exosomes [88].

While secreted exosomes from a range of cell types exhibit some common shared contents, they also express molecules that reflect their cells of origin $[44,58,71]$ and their microenvironment (e.g., culture conditions) [37, 9193].

Exosomes are released from producer cells with stable phenotypes. The possibility of changing the phenotype of the exosomes represents a novel therapeutic strategy for cell-free regenerative medicine. Pre-treating the producer cells with different cytokine cocktails, etc., to drive a specific response [94], or stimulating/exposing producer cells - in effect mimicking cells' responses to a local diseased/damaged environment after implantation - can result in exosomes therapeutically suited to specific indication, as in cancer vaccines [95]. 


\subsection{Preparation, isolation and manufacture of stem cell-derived exosomes}

Efforts to harvest purified exosomes in clinically significant quantities are limited by the lack of tools and methods to differentiate them from microparticles in general and isolate different subsets. Most cell types produce exosomes; those produced by cultured cells are isolated from the conditioned media (Figure 1). Additionally, the yield from different cell types varies significantly. Within MSCs, for example, the production of exosomes from ES cell-derived MSCs is up to seventimes that from cord blood- or bone marrow-derived MSCs, suggesting a direct correlation between the donor cell 'immaturity' and exosome yield [96].

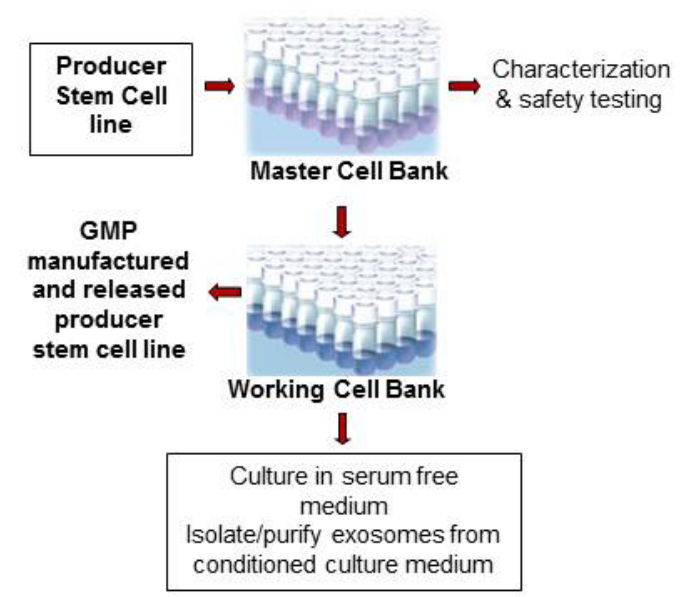

Methods based on $\downarrow$

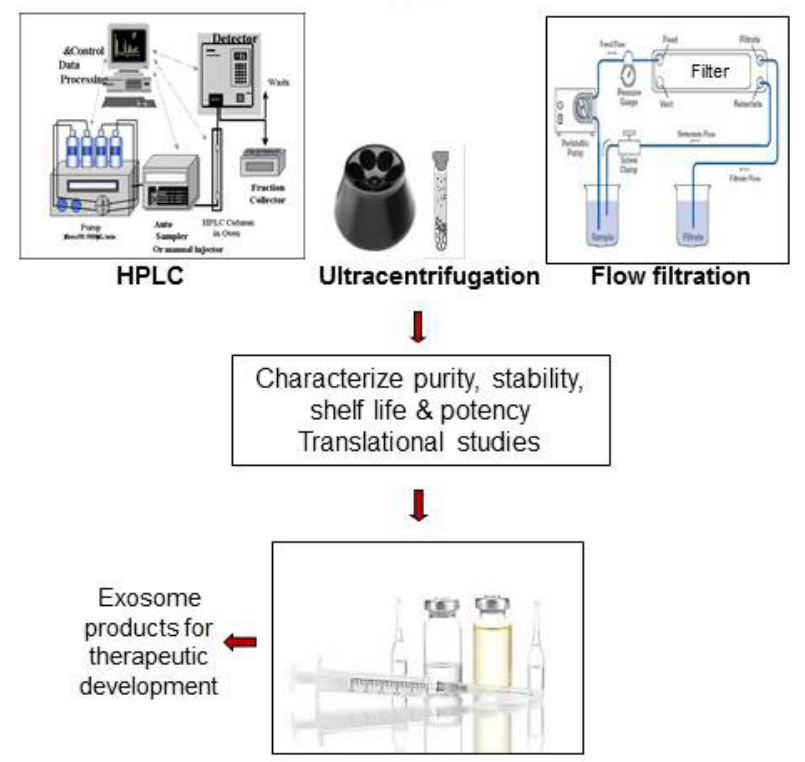

Figure 1. Overview of the isolation and manufacture of stem cellderived exosomes
As yet, there is no agreed or standardized method for the preparation and purification of exosomes from cellconditioned culture media (Table 2). MVs, exosomes, debris and culture media contaminants are all contained in the conditioned medium. Serum-free defined media may be used to reduce contamination with a serum or its components. Also, it is difficult to analytically distinguish exosomes from other membrane vesicles due to the limitations of commonly-used separation procedures, namely ultracentrifugation and flow cytometry [97]. The overall size of exosomes $(<100 \mathrm{~nm})$ has been an important criterion for distinguishing them from the other larger membrane-bound microvesicle secretions. Among current methods (differential centrifugation, discontinuous density gradients, immunoaffinity, ultrafiltration and high performance liquid chromatography (HPLC), differential centrifugation is the most commonly used for exosome isolation, which utilizes an increasing centrifugal force from 2000xg to $10,000 \times$ g to separate the medium- and larger-sized particles and cell debris from the exosome pellet at 100,000xg [33, 98-100]. Although crude and non-specific, this method has been reported to allow for the significant separation/collection of exosomes from a conditioned medium. However, protein aggregates, genetic materials, particulates from media and cell debris are common contaminants. To enhance the specificity of exosome purification, sequential centrifugation has been combined with ultrafiltration [98], or equilibrium density gradient centrifugation in a sucrose density gradient or Optiprep ${ }^{\circledR}$, to provide for the greater purity of the exosome preparation (flotation density $1.1-1.2 \mathrm{~g} / \mathrm{ml}$ ) [99] or sugar cushion $[29,33,101]$.

The isolation of exosomes based on size is another option. Ultrafiltration can be used to purify exosomes without compromising biological activity. Membranes with different pore sizes - such as $100 \mathrm{kDa}$ molecular weight cut-off (MWCO) and gel filtration to eliminate smaller particles - have been used to avoid the use of a nonneutral $\mathrm{pH}$ or non-physiological salt concentration [33, 100]. Currently available tangential flow filtration (TFF) systems are scalable (to $>10,000 \mathrm{~L}$ ), purify and concentrate the exosome fractions [29] (www.pall.com), and are less time consuming than differential centrifugation. HPLC can also be used to purify exosomes to homogeneouslysized particles and preserve their biological activity as the preparation is maintained at a physiological $\mathrm{pH}$ and salt concentration [68, 88]. Although the purity of the exosome preparation is high, this method has poor scalability. 


\begin{tabular}{|c|c|c|c|}
\hline Isolation Method & $\begin{array}{l}\text { Indicator of Exosome Sample } \\
\text { Purity for Clinical Use }\end{array}$ & Advantages & Disadvantages \\
\hline $\begin{array}{l}\text { Differential } \\
\text { centrifugation }[22,33,98]\end{array}$ & $\begin{array}{l}\text { Ratio of total MHC class II } \\
\text { molecules per mg total protein (1- } \\
2 \% \text { of total protein being MHC II } \\
\text { class); absence of non-exosomal } \\
\text { proteins, haptoglobin and human } \\
\text { serum albumin }(<1-2 \% \text { of overall) } \\
\text { using SDS-PAGE and ELISA; low } \\
\text { levels of DNA ( }<50 \mathrm{ng} / \mathrm{ml})[33]\end{array}$ & $\begin{array}{l}\text { Potential for sterile } \\
\text { preparations }[33,98]\end{array}$ & $\begin{array}{l}\text { Time consuming; low recovery, } \\
\text { poor reproducibility due to } \\
\text { operator variability [33] } \\
\text { Pellet re-suspension difficult [99] } \\
\text { Contamination with other } \\
\text { microparticles of overlapping size } \\
\text { distribution, protein aggregates, } \\
\text { particulates from media and cell } \\
\text { debris [33, 100, 101] }\end{array}$ \\
\hline $\begin{array}{l}\text { Ultrafiltration (500 kDa } \\
\text { MWCO hollow fibre) + } \\
\text { centrifugation using } \\
\left.\text { sucrose }-\mathrm{D}_{20}\right) \text { density } \\
\text { cushion }\left(1.21 \mathrm{~g} / \mathrm{cm}^{3}\right)[33]\end{array}$ & $\begin{array}{l}\text { Ratio of total MHC class II } \\
\text { molecules per mg total protein (1- } \\
2 \% \text { of total protein being MHC II } \\
\text { class); absence of non-exosomal } \\
\text { proteins, haptoglobin and human } \\
\text { serum albumin }(<1-2 \% \text { of overall) } \\
\text { using SDS-PAGE and ELISA; low } \\
\text { levels of DNA ( }<50 \mathrm{ng} / \mathrm{ml})[33]\end{array}$ & $\begin{array}{l}\text { Potentially high enrichment of } \\
\text { exosomes; useful for clinical } \\
\text { applications [33] } \\
\text { Hollow fibre cartridge removed } \\
\text { dead cells and debris by using } \\
\text { membranes with different pore } \\
\text { sizes (i.e., } 100 \mathrm{kDa} \text { MWCO) } \\
\text { The protein content of samples } \\
\text { remained consistent [33] } \\
\text { Sterile preparations } \\
\text { Less time consuming than } \\
\text { ultracentrifugation [100] }\end{array}$ & $\begin{array}{l}\text { Filtration reduced scalability of } \\
\text { the subsequent centrifugation } \\
\text { method [99] }\end{array}$ \\
\hline $\begin{array}{l}\text { Ultrafiltration } 100 \mathrm{kDa} \\
\text { MWCO membrane } \\
\text { (Minimate TFF capsule } \\
\text { system, PALL } \\
\text { Corporation, Ann Arbor, } \\
\text { MI) and sequential } \\
\text { ultracentrifugation onto } \\
\text { a sucrose gradient [29] }\end{array}$ & $\begin{array}{l}\text { Protein concentration } \\
\text { (refractometry and Bradford dye } \\
\text { assay) of final exosomal } \\
\text { preparation [29] }\end{array}$ & $\begin{array}{l}\text { Used to isolate exosomes for } \\
\text { protein characterization } \\
\text { studies }\end{array}$ & \\
\hline $\begin{array}{l}\text { HPLC + centrifugation } \\
{[30,88]}\end{array}$ & $\begin{array}{l}\text { Presence of CD9 (western blot) } \\
\text { and homogenous in size (DLS), } \\
\text { flotation density } 1.11-1.16 \mathrm{~g} / \mathrm{ml}, \\
\text { proteins MW range from } 20 \text { to } 250 \\
\mathrm{kDa}[30] \\
1.5 \mathrm{mg} \text { of exosomes from } 1 \mathrm{~L} \text { of } \\
\text { conditioned medium; doses of } 0.3 \\
\text { or } 0.4 \mu \mathrm{g} \text { per mouse [88] }\end{array}$ & $\begin{array}{l}\text { High throughput } \\
\text { High purity (homogeneous } \\
\text { sized particles) } \\
\text { Biological activity preserved } \\
\text { as preparation is maintained } \\
\text { at physiological pH and salt } \\
\text { concentration [99] }\end{array}$ & $\begin{array}{l}\text { Low yields } \\
\text { Expensive equipment and poor } \\
\text { scalability }[30,99]\end{array}$ \\
\hline $\begin{array}{l}\text { Differential } \\
\text { ultracentrifugation (first } \\
\text { using sugar cushion } \\
\text { (30\% sucrose/ } \mathrm{D}_{2} \mathrm{O} \\
\text { cushion for I hour) [101] }\end{array}$ & $\begin{array}{l}\text { Expressed as ratio of particle to } \\
\text { protein high purity at } 3.3 \times 10^{10} \\
\mathrm{P} / \mu \mathrm{g} \text {; impure if }<1.5 \times 10^{9} \mathrm{P} / \mu \mathrm{g} \\
{[101]}\end{array}$ & $\begin{array}{l}\text { Sugar cushion resulted in high } \\
\text { purity and greater elimination of } \\
\text { non-vesicular proteins [101] } \\
\text { Useful for high through put and } \\
\text { clinical preparations[101] }\end{array}$ & $\begin{array}{l}\text { Applicable for purification of } \\
\text { large amounts of exosomes }\end{array}$ \\
\hline Affinity beads $[98,102]$ & Not determined & $\begin{array}{l}\text { Easy to use with fewer steps } \\
\text { than centrifugation methods } \\
\text { High specificity, dependent on } \\
\text { choice of marker for } \\
\text { immobilization [98] }\end{array}$ & $\begin{array}{l}\text { Selection of exosome population } \\
\text { subset; not intended for } \\
\text { purification of large amounts of } \\
\text { exosomes [98] } \\
\text { Difficulty in completely } \\
\text { removing antibodies from } \\
\text { sample and eluting fully } \\
\text { functioning exosomes [98] }\end{array}$ \\
\hline $\begin{array}{l}\text { Polymer-based } \\
\text { precipitation (ExoQuick) } \\
\text { (www.systembio.com) }\end{array}$ & $\begin{array}{l}\text { Number of particles within size } \\
\text { range detected NanoSight } \\
\text { tracking system [100] }\end{array}$ & $\begin{array}{l}\text { Potentially high yields } \\
\text { Fewer steps than } \\
\text { centrifugation methods }\end{array}$ & $\begin{array}{l}\text { No method for removing } \\
\text { polymers from exosome sample } \\
\text { Pellet difficult to re-suspend [100] }\end{array}$ \\
\hline $\begin{array}{l}\text { Flow field-flow } \\
\text { fractionation (FlFFF)[35] }\end{array}$ & Not determined & $\begin{array}{l}\text { Analytical technique for } \\
\text { fractionation of exosomes, } \\
\text { useful for morphological and } \\
\text { protein characterization }\end{array}$ & $\begin{array}{l}\text { Not for large-scale preparation } \\
\text { of exosomes }\end{array}$ \\
\hline
\end{tabular}

Abbreviations: Dynamic light scattering (DLS); Flow field-flow fractionation (FIFFF); high pressure liquid chromatography (HPLC); kiloDalton (kDa); molecular weight cut off (NMWCO); tangential flow filtration (TFF)

Table 2. Exosome isolation methods from cell culture media 
Immunoaffinity is a highly scalable technique using antibodies recognizing exosome-associated antigens conjugated to magnetic beads, chromatography matrices, plates or microfluidic devices [67, 88, 98, 102]. The antibodies can be used by themselves or in combination. For example, ExoTest ${ }^{\circledR}$ kits feature anti-CD63, -CD81 or CD9 antibodies immobilized on 96 well plates for exosome capture and characterization (www.HansaBioMed.eu). Other affinity-capture methods use lectins which bind to specific saccharide residues on the exosome surface (www.AethlonMedical.com). The targets or markers for affinity capture need to be identified to optimize the high specificity offered by this technique.

Exosomes can also be purified by using differential solubility in volume-excluding polymers, such as polyethylene glycols (PEGs) and low-speed centrifugation or filtration. Based on this concept, System Biosciences has released a proprietary reagent called ExoQuick ${ }^{\circledR}$ that can be added to the conditioned cell media to precipitate the exosomes (www.SystemBio.com). The procedure has been reported as being fast and straightforward. However, it is not specific for exosomes and pellet re-suspension is difficult [100].

Flow field-flow fractionation (FlFFF) is an elution-based technique that is used to separate and characterize macromolecules (e.g., proteins) and nano- to micro-sized particles (e.g., organelles and cells) and which has been successfully applied to fractionate exosomes from hNSCs culture media [35].

Defining the purity of an exosomal preparation is critical to defining the product prior to any translational development [101]. The production of clinical-grade exosome products would require current Good Manufacturing Practice (cGMP). Exosomal products are more stable and easier to store and transport to the clinical site than stem cells [47]. The use of clinical-grade immortalized stem cell lines can reduce the time required for cell production, allowing cell banking and scalability, and thereby reducing production costs, and can also be of value in a strategy for GMP manufacturing [68, 88]. Also essential for the development of exosomes products are release assays, required for establishing the storage, shelf life and stability of the exosome products prior to clinical trials $[46,103]$.

\section{Developing a stem cell-derived exosome product}

\subsection{Therapeutics}

For clinical translation to be realized, it is necessary to characterize the physiochemical properties/phenotype of the purified exosome population along with the content and/or cargo of these vesicles in terms of proteins and small RNAs (Table 1). By addressing in an unbiased manner the genomic and proteomic content of the purified exosomes, it may be possible to predict the cellular targets and pathways that may be influenced.

Therapeutic approaches based on the delivery of miRNAs are currently being explored for cerebrovascular, myocardial and peripheral ischaemia. MSC-derived exosomes have been found to increase the miRNA-133b level when exposed to middle cerebral artery occlusion (MCAo) brain extracts [104]. MiRNA-133b is substantially down-regulated in the rat brain after MCAo. The therapeutic approach is to increase miRNA-133b in the brain tissue via exosomes to stimulate neurite outgrowth and improve functional recovery after stroke. Similarly, MSC-derived exosomes were also able to provide protection against myocardial ischaemia and treat myocardial infarction through the expression of higher levels of precursor forms of hsa-let- $7 \mathrm{~b}$ and hsa-let-7g miRNAs. CD34+ stem cell-derived exosomes are described as inducing angiogenic activity in isolated endothelial cells and in murine models of vessel growth. The benefit of CD34+ cell therapy for functional recovery after ischaemic injury could be induced by the exosomemediated transfer of angiogenic factors to surrounding cells. Preliminary data on the mechanism that may mediate the enhanced potency of CD34+-derived exosomes have shown that the pro-angiogenic miRNAs 126 and 130a were highly expressed in CD34+ exosomes compared with other unselected MNCs [34].

In another study, protein profiling led to the identification of $20 \mathrm{~S}$ proteasome using the ExoCarta database as a candidate exosome protein, with the therapeutic potential to ameliorate tissue damage after myocardial infarction [69]. Exosomes - as active components of conditioned medium from human ES cellderived MSCs - injected into swine and murine models of ischaemia/reperfusion injury reduced the infarct size [30]; from bone marrow-derived MSCs, they accelerated repair in mouse models of acute kidney injury [77]; and from liver-derived stem cells, they induced proliferation and apoptosis resistance in cultured human hepatocytes [76]. Many more detailed functional studies are required to discover other candidate proteins and their therapeutic potential.

\subsection{Clinical experience}

Only one stem cell-derived exosome product has been used clinically to date [105]. In this first attempt, the administration of escalating doses of exosomes derived from donor bone marrow MSCs into a patient suffering from severe therapy-refractory cutaneous and intestinal graft-versus-host disease grade IV was found to be well 
tolerated and led to a significant and sustainable decrease of symptoms. A small number of clinical trials are currently investigating dendritic cell-derived exosomes for immunotherapy or vaccination in severe cancers, such as non-small lung (Phase II, NCT01159288) [106], glioma (Phase I NCT01550523) [107] and gastric (Observational, NCT01779583), and with Phase I trials in non-small lung small lung ([108], colorectal [109] and melanoma [110] completed. Interestingly, the use of plant-derived exosomes as vehicles to deliver curcumin to treat colon cancer is also under scrutiny (Phase I, NCT01294070).

\subsection{Advantages/limitations of exosome therapeutics}

The research to date indicates that stem cell-derived exosomes potentially have significant clinical utility. Exosome-based, cell-free therapies - in contrast to cellbased therapies in regenerative medicine - can be generally easier to manufacture and prima facie safer, as they are non-viable and will not form tumours. By replacing the administration of live cells with their secreted exosomes, many of the safety concerns and limitations associated with the transplantation of viable replicating cells could be mitigated.

Stem cell-derived exosomes have generally been found to be less immunogenic than parental cells, as a result of a lower content of membrane-bound proteins, such as MHC complex molecules [10]. Thus, 'off-the-shelf' products may be readily developed using exosomes with negligible alloimmunogenicity.

Cell-free products offer a number of advantages compared to cell transplantation. Exosomes - in a manner similar to conventional biopharmacological products can be standardized and tested in terms of dose and biological activity. Exosomes can be stored without potentially toxic cryopreservatives at $-20^{\circ} \mathrm{C}$ for six months with no loss to their biochemical activity [100].

An important feature of exosomes is the encapsulation and protection of their contents from degradation in vivo, thereby potentially preventing some of the problems associated with small soluble molecules such as cytokines, growth factors, transcription factors and RNAs, which are rapidly degraded [28].

The durability of exosomes in culture allows for the acquisition of large quantities of exosomes through their collection from a culture medium in which the exosomes are secreted over periods of time.

Scalable systems for exosome production to support large-scale commercially viable manufacturing processes need to be developed.
While exosomes exhibit several attractive features as a therapeutic agent, there are also potential limitations to be considered as well. Exosomes contain a mixture of biologically active molecules, some of which seem to have beneficial effects, whereas others might have detrimental (e.g., proinflammatory) effects under certain conditions. Whether exosomes will turn out to be superior to angiogenic drugs or purified recombinant growth factors and other peptides within the context of cell-free approaches to tissue regeneration remains to be seen.

In addition, these naturally-occurring secreted membrane vesicles are better tolerated in the body, as evidenced by their ubiquitous presence in biological fluids, and have an intrinsic homing ability. In contrast to cell-based therapy, stem cell-derived exosomes provide an 'off-the-shelf' therapeutic product and will incur less manufacturing and storage costs.

Similarly, most stem cells can be readily genetically modified, either by integrating viruses or episomal transfection. It is known that the overexpression or knock-down of miRNAs can result in similar over- or under-expression in exosomal cargo [79, 104, 111-113]. This has been exploited in preclinical studies where genetically modified exosomes have shown relevant therapeutic outcomes [78, 104, 111-114].

\subsection{Clinical and regulatory considerations}

While the application of stem cell-derived exosomes remains largely untested by regulatory authorities in advance of clinical trials, it is likely that these products will be seen in a similar way to their parent cells.

Safety testing will focus on systemic bio-distribution, toxicity/tolerability and half-life studies. Compared to stem cell therapy, exosomal products can be delivered more readily by less sophisticated and more conventional delivery devices as the formulation and stability will be similar to biologics. Repeat administration and even selfadministration may also be possible in the future due to more straightforward product presentation. In addition, the much lower cost of such goods will be attractive to healthcare funders.

\section{Future scope}

The number of peer-reviewed publications focusing on exosomes has increased exponentially over the past decade. The newly founded International Society for Extracellular Vesicles (ISEV) is seeing a rapid rise in the number of presentations on the therapeutic use of exosomes. Much excitement and promise has been generated around the use of exosomes in cell-free regenerative medicine, which offers the potential for 
safer, low risk products to cover a wider range of applications. Databases such as ExoCarta have facilitated the sharing of data regarding the genomics and proteomics of exosomes. As this data continues to accrue, it will become important to determine which factors are most relevant to exosome functions. Also key to exosome product translation will be advances in GMP supply and the production of clinical grade products, product characterization and potency assays, preclinical proof of efficacy and the identification of target populations. Although some exosomal preparations are already being administered in the clinic, the regulatory road map for stem cell-derived exosome product translation to clinical application will need to be established soon so as to keep pace with research demands.

\section{Compliance with ethical research standards}

Conflicts of interest: I. Vishnubhatla, R. Corteling, L. Stevanto, C. Hicks and J. Sinden are ReNeuron employees. No part of this study was performed on any human or animal subjects.

\section{References}

[1] Matsa E, Sallam K and Wu JC (2014) Cardiac stem cell biology: glimpse of the past, present, and future. Circulation Research 114: 21-27.

[2] Sinden JD, Vishnubhatla I and Muir KW (2012) Prospects for stem cell-derived therapy in stroke. Progress in Brain Research 201: 119-167.

[3] Raval Z and Losordo DW (2013) Cell therapy of peripheral arterial disease: from experimental findings to clinical trials. Circulation Research 112: 1288-1302.

[4] Cieri N, Mastaglio S, Oliveira G, Casucci M, Bondanza A, et al. (2014) Adoptive immunotherapy with genetically modified lymphocytes in allogeneic stem cell transplantation. Immunological Reviews 257: 165-180.

[5] Gnecchi M, Zhang Z, Ni A and Dzau VJ (2008) Paracrine mechanisms in adult stem cell signaling and therapy. Circulation Research 103: 1204-1219.

[6] Hicks C, Stevanato L, Stroemer RP, Tang E, Richardson $S$, et al. (2013) In vivo and in vitro characterization of the angiogenic effect of CTX0E03 human neural stem cells. Cell Transplantation 22: 1541-1552.

[7] Katare R, Stroemer P, Hicks C, Stevanato L, Patel S, et al. (2014) Clinical-grade human neural stem cells promote reparative neovascularization in mouse models of hindlimb ischemia. Arteriosclerosis, Thrombosis, and Vascular Biology 34: 408-418.

[8] Bi B, Schmitt R, Israilova M, Nishio H and Cantley LG (2007) Stromal cells protect against acute tubular injury via an endocrine effect. Journal of the American Society of Nephrology: JASN 18: 2486-2496.
[9] Parekkadan B, van Poll D, Suganuma K, Carter EA, Berthiaume F, et al. (2007) Mesenchymal stem cellderived molecules reverse fulminant hepatic failure. PloS One 2: e941.

[10] Yeo RWY, Lai RC, Tan KH and Lim SK (2013) Exosome: a novel and safer therapeutic refinement of mesenchymal stem cell. InTech Exosomes and Microvesicles 1: 1-12.

[11] Camussi G, Deregibus MC and Cantaluppi V (2013) Role of stem-cell-derived microvesicles in the paracrine action of stem cells. Biochemical Society transactions 41: 283-287.

[12] Timmers L, Lim SK, Arslan F, Armstrong JS, Hoefer IE, et al. (2007) Reduction of myocardial infarct size by human mesenchymal stem cell conditioned medium. Stem cell research 1: 129-137.

[13] Timmers L, Lim SK, Hoefer IE, Arslan F, Lai RC, et al. (2011) Human mesenchymal stem cell-conditioned medium improves cardiac function following myocardial infarction. Stem cell research 6: 206-214.

[14] Lai RC, Chen TS and Lim SK (2011) Mesenchymal stem cell exosome: a novel stem cell-based therapy for cardiovascular disease. Regenerative medicine 6: 481-492.

[15] Bang C and Thum T (2012) Exosomes: new players in cell-cell communication. The International Journal of Biochemistry and Cell Biology 44: 2060-2064.

[16] Simons M and Raposo G (2009) Exosomes - vesicular carriers for intercellular communication. Current Opinion in Cell Biology 21: 575-581.

[17] Thery C (2011) Exosomes: secreted vesicles and intercellular communications. F1000 Biology Reports 3: 15.

[18] Chivet M, Javalet C, Hemming F, Pernet-Gallay K, Laulagnier K, et al. (2013) Exosomes as a novel way of interneuronal communication. Biochemical Society Transactions 41: 241-244.

[19] Smalheiser NR (2007) Exosomal transfer of proteins and RNAs at synapses in the nervous system. Biology Direct 2: 35.

[20] Redis RS, Calin S, Yang Y, You MJ and Calin GA (2012) Cell-to-cell miRNA transfer: from body homeostasis to therapy. Pharmacology and Therapeutics 136: 169-174.

[21] Andre F, Schartz NE, Movassagh M, Flament C, Pautier P, et al. (2002) Malignant effusions and immunogenic tumour-derived exosomes. Lancet 360: 295-305.

[22] Raposo G, Nijman HW, Stoorvogel W, Liejendekker R, Harding CV, et al. (1996) B lymphocytes secrete antigen-presenting vesicles. The Journal of Experimental Medicine 183: 1161-1172.

[23] Wolfers J, Lozier A, Raposo G, Regnault A, Thery C, et al. (2001) Tumor-derived exosomes are a source of shared tumor rejection antigens for CTL crosspriming. Nature Medicine 7: 297-303. 
[24] Clayton A (2012) Cancer cells use exosomes as tools to manipulate immunity and the microenvironment. Oncoimmunology 1: 78-80.

[25] Camussi G, Deregibus MC and Tetta C (2010) Paracrine/endocrine mechanism of stem cells on kidney repair: role of microvesicle-mediated transfer of genetic information. Current Opinion in Nephrology and Hypertension 19: 7-12.

[26] Ratajczak J, Miekus K, Kucia M, Zhang J, Reca R, et al. (2006) Embryonic stem cell-derived microvesicles reprogram hematopoietic progenitors: evidence for horizontal transfer of mRNA and protein delivery. Leukemia 20: 847-856.

[27] Eldh M, Ekstrom K, Valadi H, Sjostrand M, Olsson B, et al. (2010) Exosomes communicate protective messages during oxidative stress; possible role of exosomal shuttle RNA. PloS One 5: e15353.

[28] Valadi H, Ekstrom K, Bossios A, Sjostrand M, Lee JJ, et al. (2007) Exosome-mediated transfer of mRNAs and microRNAs is a novel mechanism of genetic exchange between cells. Nature Cell Biology 9: 654659.

[29] Kim HS, Choi DY, Yun SJ, Choi SM, Kang JW, et al. (2012) Proteomic analysis of microvesicles derived from human mesenchymal stem cells. Journal of Proteome Research 11: 839-849.

[30] Lai RC, Arslan F, Lee MM, Sze NS, Choo A, et al. (2010) Exosome secreted by MSC reduces myocardial ischemia/reperfusion injury. Stem Cell Research 4: 214-222.

[31] Xin H, Li Y, Cui Y, Yang JJ, Zhang ZG, et al. (2013) Systemic administration of exosomes released from mesenchymal stromal cells promote functional recovery and neurovascular plasticity after stroke in rats. Journal of Cerebral Blood Flow and Metabolism: Official Journal of the International Society of Cerebral Blood Flow and Metabolism.

[32] He J, Wang Y, Sun S, Yu M, Wang C, et al. (2012) Bone marrow stem cells-derived microvesicles protect against renal injury in the mouse remnant kidney model. Nephrology 17: 493-500.

[33] Lamparski HG, Metha-Damani A, Yao JY, Patel S, Hsu DH, et al. (2002) Production and characterization of clinical grade exosomes derived from dendritic cells. Journal of Immunological Methods 270: 211-226.

[34] Sahoo S, Klychko E, Thorne T, Misener S, Schultz $\mathrm{KM}$, et al. (2011) Exosomes from human CD34(+) stem cells mediate their proangiogenic paracrine activity. Circulation Research 109: 724-728.

[35] Kang D, Oh S, Ahn SM, Lee BH and Moon MH (2008) Proteomic analysis of exosomes from human neural stem cells by flow field-flow fractionation and nanoflow liquid chromatography-tandem mass spectrometry. Journal of Proteome Research 7: 34753480 .
[36] Drago D, Cossetti C, Iraci N, Gaude E, Musco G, et al. (2013) The stem cell secretome and its role in brain repair. Biochimie 95: 2271-2285.

[37] Thery C, Ostrowski M and Segura E (2009) Membrane vesicles as conveyors of immune responses. Nature Reviews Immunology 9: 581-593.

[38] Gyorgy B, Szabo TG, Pasztoi M, Pal Z, Misjak P, et al. (2011) Membrane vesicles, current state-of-the-art: emerging role of extracellular vesicles. Cellular and Molecular Life Sciences: CMLS 68: 2667-2688.

[39] Raposo G and Stoorvogel W (2013) Extracellular vesicles: exosomes, microvesicles, and friends. The Journal of Cell Biology 200: 373-383.

[40] Hugel B, Martinez MC, Kunzelmann C and Freyssinet JM (2005) Membrane microparticles: two sides of the coin. Physiology 20: 22-27.

[41] Harding C, Heuser J and Stahl P (1983) Receptormediated endocytosis of transferrin and recycling of the transferrin receptor in rat reticulocytes. The Journal of Cell Biology 97: 329-339.

[42] Johnstone RM, Adam M, Hammond JR, Orr L and Turbide C (1987) Vesicle formation during reticulocyte maturation. Association of plasma membrane activities with released vesicles (exosomes). The Journal of Biological Chemistry 262: 9412-9420.

[43] Pan BT, Teng K, Wu C, Adam M and Johnstone RM (1985) Electron microscopic evidence for externalization of the transferrin receptor in vesicular form in sheep reticulocytes. The Journal of Cell Biology 101: 942-948.

[44] Fevrier B and Raposo G (2004) Exosomes: endosomalderived vesicles shipping extracellular messages. Current Opinion in Cell Biology 16: 415-421.

[45] Delcayre A and Le Pecq JB (2006) Exosomes as novel therapeutic nanodevices. Current Opinion in Molecular Therapeutics 8: 31-38.

[46] Marcus ME and Leonard JN (2013) FedExosomes: engineering therapeutic biological nanoparticles that truly deliver. Pharmaceuticals 6: 659-680.

[47] Yeo RW, Lai RC, Zhang B, Tan SS, Yin Y, et al. (2013) Mesenchymal stem cell: an efficient mass producer of exosomes for drug delivery. Advanced Drug Delivery Reviews 65: 336-341.

[48] Kooijmans SA, Vader P, van Dommelen SM, van Solinge WW and Schiffelers RM (2012) Exosome mimetics: a novel class of drug delivery systems. International Journal of Nanomedicine 7: 1525-1541.

[49] Camussi G, Deregibus MC, Bruno S, Cantaluppi V and Biancone L (2010) Exosomes/microvesicles as a mechanism of cell-to-cell communication. Kidney International 78: 838-848.

[50] Thery C, Boussac M, Veron P, Ricciardi-Castagnoli P, Raposo G, et al. (2001) Proteomic analysis of dendritic cell-derived exosomes: a secreted subcellular compartment distinct from apoptotic vesicles. Journal of Immunology 166: 7309-7318. 
[51] Chaput N and Thery C (2011) Exosomes: immune properties and potential clinical implementations. Seminars in Immunopathology 33: 419-440.

[52] Peche H, Heslan M, Usal C, Amigorena S and Cuturi MC (2003) Presentation of donor major histocompatibility complex antigens by bone marrow dendritic cell-derived exosomes modulates allograft rejection. Transplantation 76: 1503-1510.

[53] Denzer K, van Eijk M, Kleijmeer MJ, Jakobson E, de Groot C, et al. (2000) Follicular dendritic cells carry MHC class II-expressing microvesicles at their surface. Journal of Immunology 165: 1259-1265.

[54] Wang K, Zhang S, Weber J, Baxter D and Galas DJ (2010) Export of microRNAs and microRNAprotective protein by mammalian cells. Nucleic Acids Research 38: 7248-7259.

[55] Kosaka N, Iguchi H, Yoshioka Y, Takeshita F, Matsuki Y, et al. (2010) Secretory mechanisms and intercellular transfer of microRNAs in living cells. The Journal of Biological Chemistry 285: 17442-17452.

[56] Hsu C, Morohashi Y, Yoshimura S, Manrique-Hoyos N, Jung S, et al. (2010) Regulation of exosome secretion by Rab35 and its GTPase-activating proteins TBC1D10A-C. The Journal of Cell Biology 189: 223-232.

[57] Chen TS and Lim SK (2013) Measurement of precursor miRNA in exosomes from human ESCderived mesenchymal stem cells. Methods in Molecular Biology 1024: 69-86.

[58] Collino F, Deregibus MC, Bruno S, Sterpone L, Aghemo G, et al. (2010) Microvesicles derived from adult human bone marrow and tissue specific mesenchymal stem cells shuttle selected pattern of miRNAs. PloS One 5: e11803.

[59] Chen TS, Lai RC, Lee MM, Choo AB, Lee CN, et al. (2010) Mesenchymal stem cell secretes microparticles enriched in pre-microRNAs. Nucleic Acids Research 38: 215-224.

[60] Yuan A, Farber EL, Rapoport AL, Tejada D, Deniskin $\mathrm{R}$, et al. (2009) Transfer of microRNAs by embryonic stem cell microvesicles. PloS One 4: e4722.

[61] Rajendran L and Simons K (2005) Lipid rafts and membrane dynamics. Journal of Cell Science 118: 1099-1102.

[62] Zomer A, Vendrig T, Hopmans ES, van Eijndhoven M, Middeldorp JM, et al. (2010) Exosomes: Fit to deliver small RNA. Communicative and Integrative Biology 3: 447-450.

[63] Laude AJ and Prior IA (2004) Plasma membrane microdomains: organization, function and trafficking. Molecular Membrane Biology 21: 193-205.

[64] Tan SS, Yin Y, Lee T, Lai RC, Yeo RW, et al. (2013) Therapeutic MSC exosomes are derived from lipid raft microdomains in the plasma membrane. Journal of Extracellular Vesicles 2.
[65] Subra C, Laulagnier K, Perret B and Record M (2007) Exosome lipidomics unravels lipid sorting at the level of multivesicular bodies. Biochimie 89: 205-212.

[66] Trajkovic K, Hsu C, Chiantia S, Rajendran L, Wenzel $\mathrm{D}$, et al. (2008) Ceramide triggers budding of exosome vesicles into multivesicular endosomes. Science 319: 1244-1247.

[67] Mathivanan S, Fahner CJ, Reid GE and Simpson RJ (2012) ExoCarta 2012: database of exosomal proteins, RNA and lipids. Nucleic Acids Research 40: D12411244.

[68] Lai RC, Arslan F, Tan SS, Tan B, Choo A, et al. (2010) Derivation and characterization of human fetal MSCs: an alternative cell source for large-scale production of cardioprotective microparticles. Journal of Molecular and Cellular Cardiology 48: 1215-1224.

[69] Lai RC, Tan SS, Teh BJ, Sze SK, Arslan F, et al. (2012) Proteolytic Potential of the MSC Exosome Proteome: Implications for an Exosome-Mediated Delivery of Therapeutic Proteasome. International Journal of Proteomics 2012: 971907.

[70] Koh W, Sheng CT, Tan B, Lee QY, Kuznetsov V, et al. (2010) Analysis of deep sequencing microRNA expression profile from human embryonic stem cells derived mesenchymal stem cells reveals possible role of let-7 microRNA family in downstream targeting of hepatic nuclear factor 4 alpha. BMC Genomics 11 Suppl 1: S6.

[71] Taylor DD, Zacharias W and Gercel-Taylor C (2011) Exosome isolation for proteomic analyses and RNA profiling. Methods in Molecular Biology 728: 235-246.

[72] Simpson RJ, Jensen SS and Lim JW (2008) Proteomic profiling of exosomes: current perspectives. Proteomics 8: 4083-4099.

[73] Li X, Arslan F, Ren Y, Adav SS, Poh KK, et al. (2012) Metabolic adaptation to a disruption in oxygen supply during myocardial ischemia and reperfusion is underpinned by temporal and quantitative changes in the cardiac proteome. Journal of Proteome Research 11: 2331-2346.

[74] Guescini M, Genedani S, Stocchi V and Agnati LF (2010) Astrocytes and Glioblastoma cells release exosomes carrying mtDNA. Journal of Neural Transmission 117: 1-4.

[75] Lotvall J and Valadi H (2007) Cell to cell signalling via exosomes through esRNA. Cell Adhesion and Migration 1: 156-158.

[76] Herrera MB, Fonsato V, Gatti S, Deregibus MC, Sordi A, et al. (2010) Human liver stem cell-derived microvesicles accelerate hepatic regeneration in hepatectomized rats. Journal of Cellular and Molecular Medicine 14: 1605-1618.

[77] Bruno S, Grange C, Deregibus MC, Calogero RA, Saviozzi S, et al. (2009) Mesenchymal stem cellderived microvesicles protect against acute tubular injury. Journal of the American Society of Nephrology : JASN 20: 1053-1067. 
[78] Kefas B, Godlewski J, Comeau L, Li Y, Abounader R, et al. (2008) microRNA-7 inhibits the epidermal growth factor receptor and the Akt pathway and is down-regulated in glioblastoma. Cancer Research 68: 3566-3572.

[79] Cantaluppi V, Gatti S, Medica D, Figliolini F, Bruno S, et al. (2012) Microvesicles derived from endothelial progenitor cells protect the kidney from ischemiareperfusion injury by microRNA-dependent reprogramming of resident renal cells. Kidney International 82: 412-427.

[80] Bruno S, Grange C, Collino F, Deregibus MC, Cantaluppi V, et al. (2012) Microvesicles derived from mesenchymal stem cells enhance survival in a lethal model of acute kidney injury. PloS One 7: e33115.

[81] Redis RS, Berindan-Neagoe I, Pop VI and Calin GA (2012) Non-coding RNAs as theranostics in human cancers. Journal of Cellular Biochemistry 113: 14511459.

[82] Chen X, Liang H, Zhang J, Zen K and Zhang CY (2012) Secreted microRNAs: a new form of intercellular communication. Trends in Cell Biology 22: 125-132.

[83] Hunter MP, Ismail N, Zhang X, Aguda BD, Lee EJ, et al. (2008) Detection of microRNA expression in human peripheral blood microvesicles. PloS One 3: e3694.

[84] Gibbings DJ, Ciaudo C, Erhardt $\mathrm{M}$ and Voinnet $\mathrm{O}$ (2009) Multivesicular bodies associate with components of miRNA effector complexes and modulate miRNA activity. Nature Cell Biology 11: 1143-1149.

[85] Ostrowski M, Carmo NB, Krumeich S, Fanget I, Raposo G, et al. (2010) Rab27a and Rab27b control different steps of the exosome secretion pathway. Nature Cell Biology 12: 19-30; supp 11-13.

[86] Ranghino A, Cantaluppi V, Grange C, Vitillo L, Fop F, et al. (2012) Endothelial progenitor cell-derived microvesicles improve neovascularization in a murine model of hindlimb ischemia. International Journal of Immunopathology and Pharmacology 25: 75-85.

[87] Gatti S, Bruno S, Deregibus MC, Sordi A, Cantaluppi $\mathrm{V}$, et al. (2011) Microvesicles derived from human adult mesenchymal stem cells protect against ischaemia-reperfusion-induced acute and chronic kidney injury. Nephrology, Dialysis, Transplantation 26: 1474-1483.

[88] Chen TS, Arslan F, Yin Y, Tan SS, Lai RC, et al. (2011) Enabling a robust scalable manufacturing process for therapeutic exosomes through oncogenic immortalization of human ESC-derived MSCs. Journal of Translational Medicine 9: 47.

[89] Pollock K, Stroemer P, Patel S, Stevanato L, Hope A, et al. (2006) A conditionally immortal clonal stem cell line from human cortical neuroepithelium for the treatment of ischemic stroke. Experimental Neurology 199: 143-155.
[90] Tetta C, Bruno S, Fonsato V, Deregibus MC and Camussi G (2011) The role of microvesicles in tissue repair. Organogenesis 7: 105-115.

[91] Chan JKY and Lam PYP (2013) Human mesenchymal stem cells and their paracrine factors in the treatment of brain tumors. Cancer Gene Therapy: 1-5.

[92] Beninson LA and Fleshner M (2014) Exosomes: An emerging factor in stress-induced immunomodulation. Seminars in Immunology.

[93] Quesenberry PJ and Aliotta JM (2010) Cellular phenotype switching and microvesicles. Advanced Drug Delivery Reviews 62: 1141-1148.

[94] Kim SH, Lechman ER, Bianco N, Menon R, Keravala A, et al. (2005) Exosomes derived from IL-10-treated dendritic cells can suppress inflammation and collagen-induced arthritis. Journal of Immunology 174: 6440-6448.

[95] Schorey JS and Bhatnagar S (2008) Exosome function: from tumor immunology to pathogen biology. Traffic 9: 871-881.

[96] Chen TS, Yeo RWY, Arslan F, Yin Y, Tan SS, et al. (2013) Efficiency of exosome production correlates inversely with the developmental maturity of MSC Donor. J Stem Cell Res Ther 3: 145.

[97] Heijnen HF, Schiel AE, Fijnheer R, Geuze HJ and Sixma JJ (1999) Activated platelets release two types of membrane vesicles: microvesicles by surface shedding and exosomes derived from exocytosis of multivesicular bodies and alpha-granules. Blood 94: 3791-3799.

[98] Thery C, Amigorena S, Raposo G and Clayton A (2006) Isolation and characterization of exosomes from cell culture supernatants and biological fluids. Current Protocols in Cell Biology / editorial board, Juan S Bonifacino [et al] Chapter 3: Unit 322.

[99] Lai RC, Yeo RW, Tan KH and Lim SK (2013) Mesenchymal stem cell exosome ameliorates reperfusion injury through proteomic complementation. Regenerative Medicine 8: 197-209.

[100] Vlassov AV, Magdaleno S, Setterquist R and Conrad R (2012) Exosomes: current knowledge of their composition, biological functions, and diagnostic and therapeutic potentials. Biochimica et Biophysica Acta 1820: 940-948.

[101] Webber J and Clayton A (2013) How pure are your vesicles? Journal of Extracellular Vesicles 2.

[102] Clayton A, Court J, Navabi H, Adams M, Mason MD, et al. (2001) Analysis of antigen presenting cell derived exosomes, based on immuno-magnetic isolation and flow cytometry. Journal of Immunological Methods 247: 163-174.

[103] Witwer KW, Buzas EI, Bemis LT, Bora A, Lasser C, et al. (2013) Standardization of sample collection, isolation and analysis methods in extracellular vesicle research. Journal of Extracellular Vesicles 2. 
[104] Xin H, Li Y, Buller B, Katakowski M, Zhang Y, et al. (2012) Exosome-mediated transfer of miR-133b from multipotent mesenchymal stromal cells to neural cells contributes to neurite outgrowth. Stem Cells 30: 1556-1564.

[105] Kordelas L, Rebmann V, Ludwig A-K, Radtke S, Ruesing J, et al. (2014) MSC-derived exosomes: a novel tool to treat therapy-refractory graft-versushost disease. Leukemia 4: 970-973.

[106] Viaud S, Thery C, Ploix S, Tursz T, Lapierre V, et al. (2010) Dendritic cell-derived exosomes for cancer immunotherapy: what's next? Cancer Research 70: 1281-1285.

[107] Andrews DW, Resnicoff M, Flanders AE, Kenyon L, Curtis M, et al. (2001) Results of a pilot study involving the use of an antisense oligodeoxynucleotide directed against the insulinlike growth factor type I receptor in malignant astrocytomas. Journal of Clinical Oncology: Official Journal of the American Society of Clinical Oncology 19: 2189-2200.

[108] Morse MA, Garst J, Osada T, Khan S, Hobeika A, et al. (2005) A phase I study of dexosome immunotherapy in patients with advanced non-small cell lung cancer. Journal of Translational Medicine 3: 9.

[109] Dai S, Wei D, Wu Z, Zhou X, Wei X, et al. (2008) Phase I clinical trial of autologous ascites-derived exosomes combined with GM-CSF for colorectal cancer. Molecular Therapy: The Journal of the American Society of Gene Therapy 16: 782-790.
[110] Escudier B, Dorval T, Chaput N, Andre F, Caby MP, et al. (2005) Vaccination of metastatic melanoma patients with autologous dendritic cell (DC) derivedexosomes: results of the first phase I clinical trial. Journal of Translational Medicine 3: 10.

[111] Xin H, Li Y, Liu Z, Wang X, Shang X, et al. (2013) Mir-133b promotes neural plasticity and functional recovery after treatment of stroke with multipotent mesenchymal stromal cells in rats via transfer of exosome-enriched extracellular Particles. Stem Cells.

[112] Alvarez-Erviti L, Seow Y, Yin H, Betts C, Lakhal S, et al. (2011) Delivery of siRNA to the mouse brain by systemic injection of targeted exosomes. Nature Biotechnology 29: 341-345.

[113] Mittelbrunn M, Gutierrez-Vazquez C, VillarroyaBeltri C, Gonzalez S, Sanchez-Cabo F, et al. (2011) Unidirectional transfer of microRNA-loaded exosomes from $\mathrm{T}$ cells to antigen-presenting cells. Nature Communications 2: 282.

[114] Katakowski M, Buller B, Zheng X, Lu Y, Rogers T, et al. (2013) Exosomes from marrow stromal cells expressing miR-146b inhibit glioma growth. Cancer Letters 335: 201-204.

[115] Laine SK, Alm JJ, Virtanen SP, Aro HT and LaitalaLeinonen TK (2012) MicroRNAs miR-96, miR-124, and miR-199a regulate gene expression in human bone marrow-derived mesenchymal stem cells. Journal of Cellular Biochemistry 113: 2687-2695. 